\title{
IMPROVING MOISTURE DISTRIBUTION PATTERN BY USING SOME SOIL CONDITIONERS IN LOAMY SAND SOIL UNDER DRIP IRRIGATION SYSTEM
}

\author{
M. H. M. Fayed ${ }^{1}$ and M. H. M. Sheta ${ }^{2}$
}

\section{ABSTRACT}

A field experiment was carried out to study the conditioning effect of composted rice straw biochar (RSB) and synthetic cellulose polymer like carboxymethyl cellulose (CMC) on soil moisture distribution patterns, some plant growth parameters, yield and water use efficiency of squash plant (Cucurbita pepo L. var. Hybrid Revera). So, a complete randomized field experiment with three replications was conducted during the summer season of 2018 on a loamy sand soil at the Animal Production farm, Faculty of Agriculture, Al-Azhar University, Nasr City, Cairo, Egypt. The treatments were applying $R S B$ by two rates (i.e. 840 and $1680 \mathrm{~kg} \mathrm{fed}^{-1}$ ) and $C M C$ by two rates (i.e. 16.8 and $33.6 \mathrm{~kg} \mathrm{fed}^{-1}$ ) with $100 \%$ and $80 \%$ of squash water requirements. The obtained results indicated a positive effect on soil moisture distribution patterns, some plant growth parameters, yield and water use efficiency due to application of RSB with 100 and $80 \%$ of squash water requirements. Whereas, the soil was retained by the highest moisture content (18.8-15.0\%) and (15.4-10.6\%) with $100 \%$ and $80 \%$ at $(0-40 \mathrm{~cm})$, respectively. The highest productivity was 7576.69 and $6436.69 \mathrm{~kg} \mathrm{fed}^{-1}$ when adding $100 \%$ and $80 \%$ of squash water requirements, respectively. Also, the highest irrigation water use efficiency was 9.33 and $9.91 \mathrm{~kg} \mathrm{~m}^{-3}$ of irrigation water when adding $100 \%$ and $80 \%$ squash water requirements, respectively. Finally, the obtained results indicate that adding rice straw biochar (RSB) to the planting medium at a low water irrigation rate of $80 \%$ increases the efficiency of water use by preventing applied moisture from infiltrating beyond plant root zones and maximizing the amount of applied water available for plant uptake.

\section{INTRODUCTION}

$\mathrm{P}$ oor fertility (low water and nutrient retention capacity) and limited crop productivity characterize sandy soils in Egypt. One of the vital tasks in the Egyptian farming system is the search for natural organic modifications to improve their fertility.

${ }^{1}$ Lect. of Water \& Irri. Sys. Eng., Dept., Fac. of Agric., Eng., Al-Azhar Univ., Nasr City, Cairo, Egypt.

${ }^{2}$ Lect. of Soils \& Water Dept., Fac. of Agric., Al-Azhar Univ., Nasr City, Cairo, Egypt. 
The addition of biochar as organic modification has become one of the practical strategies in recent years to improve the fertility of soil and the production of crops. Soil organic matter is highly oxidized and degraded in arid and semi - arid regions, so improving soil organic matter content gains considerable attention to maintaining soil quality and productivity under these conditions (Lal, 2008 and Papathanasiou et al., 2012). Adding organic residues to sandy soils is an environmentally friendly, cost - effective and common practice and is still a desirable way to improve their fertility. As an important management strategy, crop residues can be used to enrich the soil with nutrients through its decomposition and maintain soil fertility and crop production. Farmers, however, do not know the best ways to manage such residues as rice straw and are usually burned to clean the fields after harvesting. Thus, it becomes a vital task to search for a good way to recycle crop residues through biochar production. Recently, the recycling of organic residues through the process of thermal modification to produce the biochar as a soil conditioner is considered a beneficial and popular approach to soil improvement (Chan et al., 2008;

\section{Bonelli et al., 2001 and Mohamed et al., 2015).}

Biochar properties are usually dependent on the type of biomass materials and pyrolysis process conditions (Singh $\boldsymbol{e t}$ al., 2010). In many researches, it has been shown that biochar plays an important role in maintaining high soil fertility and can also improve soil carbon sequestration (Chan et al., 2008; Lehmann et al., 2008 and Ali, 2011a).

Carboxymethyl cellulose (CMC) is a cellulose - derived ester, caused by the reaction of cellulose with sodium hydroxide and sodium monochloroacetate, resulting in a long anhydroglucose chain, which in turn produces a highly hygroscopic and viscous polymer that is non - toxic to humans (Sanz et al., 2005). As the raw material is wood or cotton linters, CMC is produced from cellulose and is therefore based on a sustainable raw material. Cellulose is not water-soluble, but CMC is made water-soluble due to a chemical reaction in the presence of sodium hydroxide between cellulose and monochloroacetic acid. This reaction takes place in an aqueous system of alcohol (Adel $\boldsymbol{e t}$ al., 2010). CMC as an amylose with many hydroxyl and carboxylic groups can absorb water and moisture, which means that the hydrogel made of it has many excellent 
properties, such as high-water content, good biodegradation and a wide low-cost source (Nie et al., 2004).

This study aim to identifying the effect of treating a loamy sand soil with rice straw biochar (RSB) and hydrogel polymer i.e. carboxymethyl cellulose (CMC) individually at applied different rates on soil water distribution pattern, growth parameters, squash marketable yields and water use efficiency at applying 100 and $80 \%$ of squash water requirements.

\section{MATERIALS AND METHODS}

The main objectives of this study were improving the properties of loamy sand soil to increase their ability to retain soil moisture in the root zone for long periods under drip irrigation system. The experiment was laid out in completely randomized block design with three replicates for each treatment was conducted. The factorial randomized block design having two factors with two levels each and two additional control. Biochar and hydrogel were the two factors. Two levels of biochar $R S B_{100}$ $100 \mathrm{~g} /$ plant pit i.e. $840 \mathrm{~kg} \mathrm{fed}{ }^{-1}, R S B_{200}-200 \mathrm{~g} /$ plant pit i.e. 1680 $\mathrm{kg} \mathrm{fed}^{-1}$ and two levels of carboxymethyl cellulose $C M C_{2}$ $2 \mathrm{~g} /$ plant pit i.e. $16.8 \mathrm{~kg} \mathrm{fed}{ }^{-1}, \mathrm{CMC}_{4}-4 \mathrm{~g} /$ plant pit i.e. 33.6 $k g \mathrm{fed}^{-1}$, and two control treatments without RSB or CMC. The applied irrigation water for one of the control treatments was $100 \%$ of squash water requirements $\left(812 \mathrm{~m}^{3} \mathrm{fed}^{-1}\right)$ which calculated by evaporation pan method and $80 \%$ of squash water requirements $\left(650 \mathrm{~m}^{3} \mathrm{fed}^{-1}\right)$ for the second control treatment and other treatments.

\section{Soil conditioners}

\section{1) Preparation of biochar}

The biochar was prepared from the experimental farm of the Department of Agronomy, Faculty of Agriculture, Al-Azhar University) Nasr City, Cairo, Egypt, through the collection of the plant residues namely rice straw. The straw samples were air dried and cut to small pieces $(1-2 \mathrm{~cm}$ ), and then converted to biochar through the continuous low pyrolysis process at a temperature of $400-500^{\circ} \mathrm{C}$ for $30 \mathrm{~min}$ as a retention time (Lu et al., 2014). The obtained biochar was crushed and sieved to a fine size $(<2 \mathrm{~mm})$ for the chemical analysis and experimental using. Table (1) show the chemical characteristics of biochar samples. 
Table (1): chemical characteristics of biochar samples

\begin{tabular}{|c|c|c|c|c|c|c|c|}
\hline$p H$ & $\begin{array}{c}E C \\
\left(d S m^{-1}\right)\end{array}$ & $\begin{array}{c}C E C \\
\left(\text { cmolc } k^{-1}\right)\end{array}$ & $\begin{array}{c}\text { Organic } \\
\text { carbon } \\
\left(\boldsymbol{g} \boldsymbol{k g}^{-1}\right)\end{array}$ & $\begin{array}{c}\text { Bulk } \\
\text { density } \\
\left(M g m^{-3}\right)\end{array}$ & $\begin{array}{c}N \\
(\%)\end{array}$ & $\begin{array}{c}\boldsymbol{P} \\
(\%)\end{array}$ & $\begin{array}{c}\boldsymbol{K} \\
(\%)\end{array}$ \\
\hline 8.20 & 2.43 & 38.4 & 438 & 0.62 & 0.67 & 0.44 & 1.19 \\
\hline
\end{tabular}

2) Carboxymethyl cellulose

The carboxymethyl cellulose (CMC) absorbent material used is produced under controlled conditions by reaction between alkali cellulose and sodium monocholora acetate. Formulation $\left(\mathrm{C}_{6} \mathrm{H}_{10} \mathrm{O}_{5}\right)$ n, molecular weight (162.2)n $\mathrm{g} \mathrm{mol}^{-1}$ and elements $(\mathrm{C}=44.4 \%, \mathrm{H}=49.4$ and $\mathrm{O}=$ $6.2 \%)$.Cellulose is also a water - insoluble plant - based polymer such as wood (eucalyptus, poplar, pine) or cotton. The molecule of cellulose consists of many rings of glucose anhydride connected in the formation of a chain. There are 100 to 6000 glucose anhydride units in each polymer chain. CMC is the cellulose ether with the most water solubility (Adel $\boldsymbol{e t}$ al., 2010 and Ali, 2011a).

\section{Soil characteristics}

Some physical and chemical characteristics of the soil at the experiment field at the farm of Animal Production Department, Faculty of Agriculture, Al-Azhar University, Nasr City, Cairo, Egypt, were studied. Four soil samples were taken to represent the area of study, dug deep down to 30 $\mathrm{cm}$ depth. The samples were air dried, ground and sieved through a $2 \mathrm{~mm}$ screen to get the fine soil which is kept for analysis. The soil characteristics were measured in the Laboratory of Soils and Water Department, Faculty of Agriculture, Al-Azhar University, Nasr City, Cairo, Egypt. Physical and chemical characteristics of the studied soil before planting were presented in Tables (2) and (3) which was determined according to Klute (1986) and Page et al., (1982).

\section{Drip irrigation network}

The field was plowed, disked, and leveled. The plot area was $10.5 \mathrm{~m}^{2}$ (length of $3.5 \mathrm{~m}$ and $3 \mathrm{~m}$ of width) i.e. 1/400 fed. The drip irrigation network was designed at the experimental field. The lateral line spacing was $1 \mathrm{~m}$ (one lateral for planting row). Emitter spacing on the lateral line was $0.5 \mathrm{~m}$ and the discharge rate of emitter was $4 \mathrm{lh}^{-1}$. The irrigation intervals were 3 days. The plant area, plant length, plant leaves number and production were measured for each treatment at all growth stages (initial, develop, mid and late stages). 


\section{Indicator crop}

Squash plants (Cucurbita pepo L. var. Hybrid Revera) were grown in $27^{\text {th }}$ April to $29^{\text {th }}$ July 2018. The mineral fertilizers were added to the soil of experimental area according to the instruction and recommendations of Agriculture Research Center. FAO (1998) gives general lengths for the four distinct growth stages and total growing period for Squash of climates and locations. This data as shown in Table (4). Only three values of Kc are required to describe and construct the crop coefficient curve, those during the initial stage $\left(K_{C \text { ini }}\right)$, the mid-season stage $\left(K_{C \text { mid }}\right)$ and at the end of the late season stage $\left(K_{C \text { end }}\right)$ as in Table (5).

\section{Determination of squash water requirements}

Water irrigation requirements were calculated by the following equations:

$$
\begin{aligned}
& E T_{o}=E_{\text {pan }} \times K_{p a n} \\
& E T_{c}=E T_{o} \times K_{c} \\
& I W R=E T_{c} \times A \times F
\end{aligned}
$$

\section{Where:}

\begin{tabular}{|c|c|c|c|c|c|c|c|c|c|c|}
\hline \multicolumn{4}{|c|}{ Particle size distribution (\%) } & \multicolumn{3}{|c|}{ 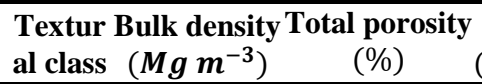 } & $\begin{array}{c}\mathbf{O M}^{1} \\
\left(g \boldsymbol{k g}^{-1}\right) \\
\end{array}$ & \multicolumn{3}{|c|}{$\begin{array}{l}\text { Moisture content (\%) } \\
\text { at: }\end{array}$} \\
\hline $\begin{array}{c}\text { Coarse } \\
\text { sand }\end{array}$ & Fine sand & Silt & Clay & \multirow{2}{*}{$\begin{array}{l}\text { Loamy } \\
\text { Sand }\end{array}$} & \multirow{2}{*}{1.67} & \multirow{2}{*}{36.98} & \multirow{2}{*}{5.4} & $\mathbf{F C}^{2}$ & $\mathbf{P W P}^{3}$ & $\mathbf{A} \mathbf{W}^{4}$ \\
\hline 10.12 & 73.80 & 7.91 & 8.17 & & & & & 13.45 & 4.27 & 9.18 \\
\hline
\end{tabular}

$$
\begin{aligned}
& \boldsymbol{E T}_{\boldsymbol{o}}: \text { Potential evapotranspiration, }\left(m m d a y^{-1}\right), \\
& \boldsymbol{E}_{\boldsymbol{p a n}}: \text { Pan evaporation, }\left(m m d a y^{-1}\right),
\end{aligned}
$$

\begin{tabular}{|c|c|c|c|c|c|c|c|c|c|}
\hline \multirow{2}{*}{\multicolumn{2}{|c|}{$\underline{p H(1: 2.5)^{1} E C\left(d^{2} m^{-1}\right)^{2}}$}} & \multicolumn{4}{|c|}{ Cations $\left(\right.$ mmolc l l $\left.^{-1}\right)$} & \multicolumn{4}{|c|}{ Anions $\left(\right.$ mmolc l $\left.^{-1}\right)$} \\
\hline & & $\mathbf{C a}^{++}$ & $\mathbf{M g}^{++}$ & $\mathrm{Na}^{+}$ & $\mathbf{K}^{+}$ & $\mathrm{CO}_{3}^{--}$ & $\mathrm{HCO}_{3}{ }^{-}$ & $\mathrm{Cl}^{-}$ & $\mathrm{SO}_{4}^{--}$ \\
\hline 8.01 & 1.69 & 4.29 & 2.16 & 9.74 & 0.68 & 0.00 & 2.47 & 6.00 & 8.40 \\
\hline
\end{tabular}

Table (2): Physical properties of soil under study

${ }^{1}$ Organic matter content, ${ }^{2}$ Field capacity, ${ }^{3}$ Permanent wilting point and ${ }^{4}$ Available water

Table (3): Chemical properties of soil under study

${ }^{1} 1: 2.5 \mathrm{w} / \mathrm{v}$ soil water suspension and ${ }^{2}$ Soil paste extract

Table (4): Lengths of crop development stages for various planting periods and climatic regions (days), (FAO, 1998)

$\begin{array}{llllllll}\text { Crop } & \begin{array}{c}\text { Initial } \\ \left(\boldsymbol{L}_{\text {ini }}\right)\end{array} & \begin{array}{c}\text { Develop } \\ \left(\boldsymbol{L}_{\text {dev }}\right)\end{array} & \begin{array}{c}\text { Mid } \\ \left(\boldsymbol{L}_{\text {mid }}\right)\end{array} & \begin{array}{c}\text { Late } \\ \left(\boldsymbol{L}_{\text {late }}\right)\end{array} & \begin{array}{c}\text { Total } \\ \text { days }\end{array} & \begin{array}{c}\text { Planting } \\ \text { date }\end{array} & \text { Region }\end{array}$

\begin{tabular}{llllllll}
\hline $\begin{array}{c}\text { Squash, } \\
\text { Zucchini }\end{array}$ & 25 & 35 & 25 & 15 & 100 & $\begin{array}{c}\text { April; } \\
\text { Dec }\end{array}$ & $\begin{array}{c}\text { Mediterranean } \\
\text { \& Arid }\end{array}$ \\
\hline
\end{tabular}


Table (5): Single crop coefficients $\left(K_{C}\right)$ and mean maximum plant heights $(m)$ for non-stressed and well managed crop, (FAO, 1998)

\begin{tabular}{|c|c|c|c|c|}
\hline Crop & $K_{\text {Cini }}$ & $K_{C \text { mid }}$ & $K_{C \text { end }}$ & Maximum crop height " $h$ ", (m) \\
\hline Squash, Zucchini & 0.5 & 0.95 & 0.75 & 0.3 \\
\hline$K_{\text {pan }}:$ & \multicolumn{4}{|c|}{$\begin{array}{l}\text { Pan coefficient from FAO tables } 1998 \text { were the wind } \\
\text { speed and relative humidity in the experimental site } \\
\text { was } 12 \mathrm{~m} \mathrm{~s}^{-1} \text { and } 50 \% \text { respectively, }\end{array}$} \\
\hline$E T_{c}:$ & \multicolumn{4}{|c|}{ Crop evapotranspiration, $\left(m m d^{2} a y^{-1}\right)$} \\
\hline$K_{c}:$ & \multicolumn{4}{|c|}{ Crop coefficient from table (5), } \\
\hline IWR : & \multicolumn{4}{|c|}{ Amounts of applied irrigation water, $\left(\right.$ Irri. $\left.^{-1}\right)$, } \\
\hline $\boldsymbol{A}:$ & \multicolumn{4}{|c|}{ Plant area, $\left(m^{2}\right)$ and } \\
\hline$F:$ & \multicolumn{4}{|c|}{ Irrigation frequency, (3 days). } \\
\hline
\end{tabular}

\section{Determination of water application time:}

The water application time was calculated as in the following equation:

Where:

$$
I_{t}=\frac{I W R}{q}
$$

$I_{\boldsymbol{t}}:$ Water application time, $(h)$ and

$\boldsymbol{q}:$ Emitter discharge, $\left(l h^{-1}\right)$.

\section{Soil moisture content ${ }^{\prime \prime} \boldsymbol{\theta}_{w}{ }^{\prime \prime}$}

To determine the soil moisture content before irrigation, the soil section was made under emitter directly and the soil samples were taken at different points on horizontal and vertical directions as in Fig. (1). After two hours of irrigation the soil samples were taken from the same section of wetting front advance at different points on horizontal and vertical directions. Soil moisture content was conducted by weighing a mass of wet soil samples, drying the soil for $24 h$ at $105^{\circ} \mathrm{C}$, and then reweighing the samples. Water content was calculated by gravimetric method (mass of water divided by the mass of dry soil) by using the following equation (Ali, 2011b):

\section{where:}

$$
\theta_{w}=\frac{m_{\text {water }}}{m_{\text {dry soil }}}=\frac{m_{\text {wet soil }}-m_{\text {dry soil }}}{m_{\text {dry soil }}}
$$

$$
\begin{aligned}
\boldsymbol{\theta}_{\boldsymbol{w}}: & \text { Gravimetric water content, }\left(g g^{-1}\right), \\
\boldsymbol{m}_{\text {water }}: & \text { Mass of water, }(g), \\
\boldsymbol{m}_{\text {dry soil }}: & \text { Mass of soil after drying, }(g) \text { and } \\
\boldsymbol{m}_{\text {wet soil }}: & \text { Mass of soil before drying, }(g) .
\end{aligned}
$$


To illustrate soil moisture distribution patterns in different depths of investigated soil under drip irrigation system at different treatments, contour plots were constructed in figures using graphic software package Surfer ${ }^{\circledR} 15$ (2018). The contour lines obtained by Kriging (Gridding Method), show the radial locations of equal moisture content percentages within the wetted soil volume.

Irrigation water use efficiency " $I W U E^{\prime \prime}$

Irrigation water use efficiency in $\left(\mathrm{kg} \mathrm{m}^{-3}\right)$ was calculated using the following formula according to Payero et al., (2008).

$$
I W U E=\frac{\text { Yield }\left(\mathrm{kg} \mathrm{fed}^{-1}\right)}{E T_{c}\left(\mathrm{~m}^{3} \mathrm{fed}^{-1}\right)}
$$

where:

IWUE: Water use efficiency, $\left(\mathrm{kg} \mathrm{m}^{-3}\right.$ water applied $)$,

$\boldsymbol{Y}:$ Yield, $\left(\mathrm{kg} \mathrm{fed}^{-1}\right)$ and

ETc: Seasonal crop evapotranspiration, $\left(\mathrm{m}^{3} \mathrm{fed}^{-1}\right)$.

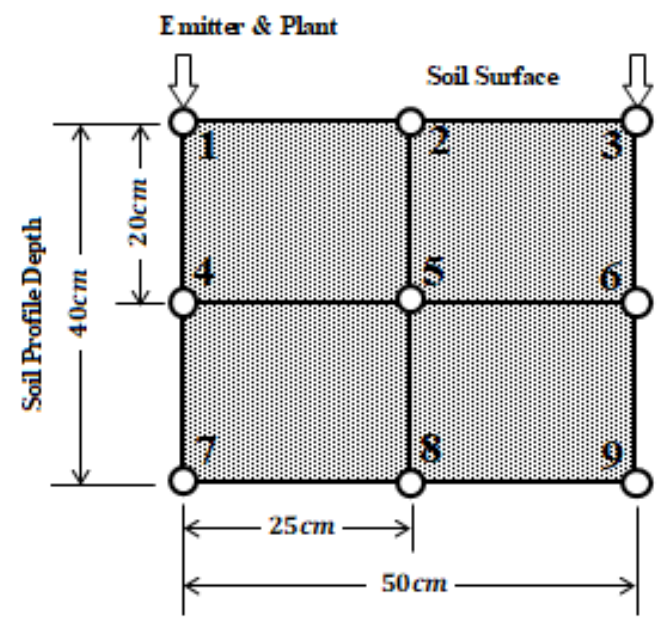

Fig. (1): A view showing the soil sampling points in the horizontal and vertical directions in the soil profile under the emitter directly.

\section{RESULTS AND DISCUSSION}

\section{Soil moisture distribution pattern}

Soil moisture distribution patterns of loamy sand soil profile as affected by different treatments were studied by soil moisture determination. Fig. (2) show the soil moisture distribution pattern before irrigation and after two hours of irrigation by $100 \%$ of squash water requirements due to the different treatments. 

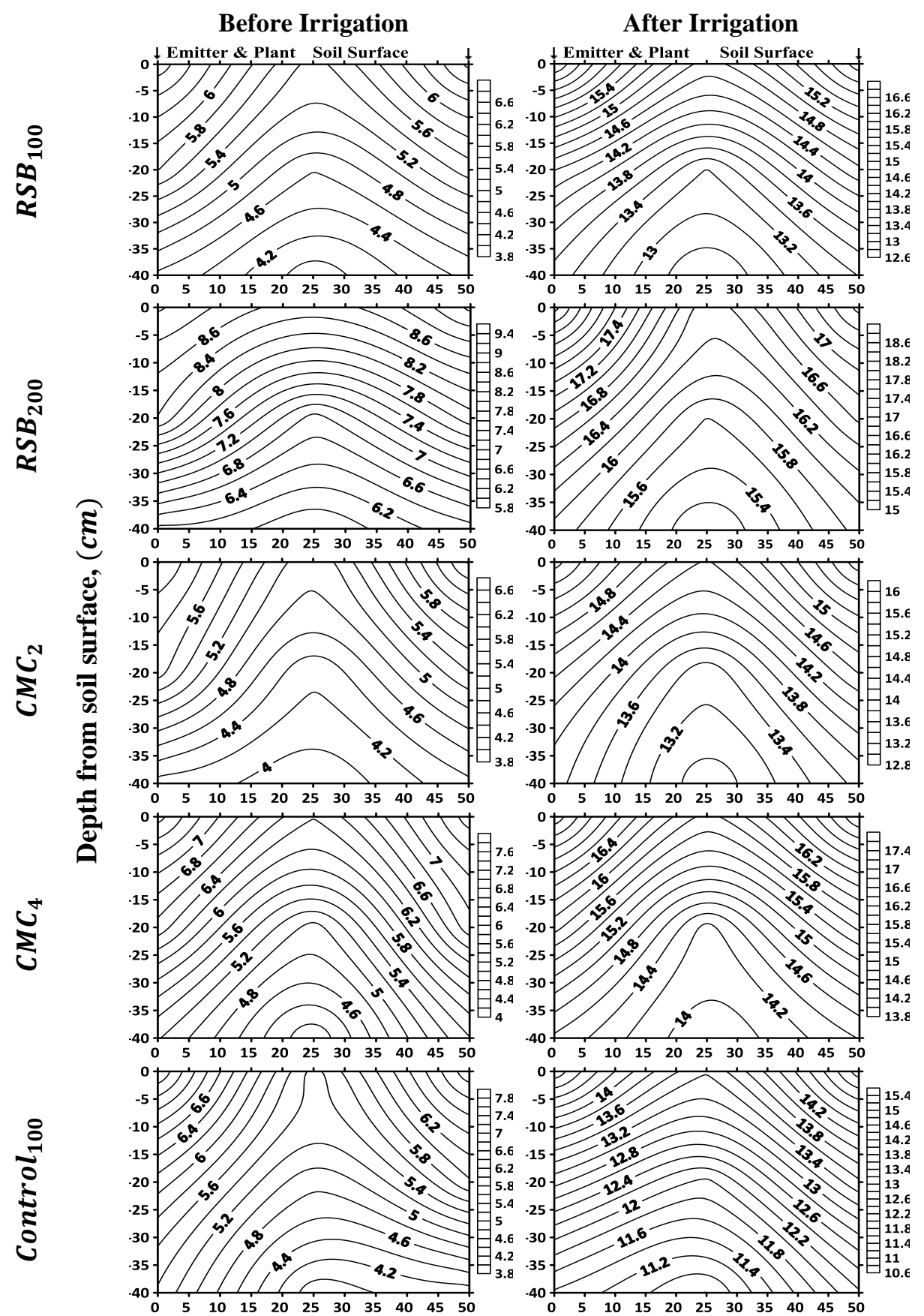

Horizontal distance from emitter or plant, $(\mathrm{cm})$

Fig. (2): The soil moisture distribution pattern in the loamy sand soil between two emitters before irrigation and after two hours of irrigation at applying $100 \%$ of crop evapotranspiration under different treatments. 
The results show that the soil under $R S B_{200}$ retained the highest values of moisture $(18.8-15 \%)$ at $(0-40 \mathrm{~cm})$, respectively followed by $C M C_{4}$ (17.6 - 13.8\%), $\operatorname{RSB}_{100}(16.8-12.6 \%)$ and $C M C_{2}(16.0-12.8 \%)$. Generally, all treatments were higher than control treatment (15.4 $10.6 \%)$. This may be due to the beneficial effect of soil conditioners for moisture retention in soil. These results agree with those of Johnson and Veltkamp (1985).

Fig. (3) show the soil moisture distribution pattern before irrigation and after two hours of irrigation by $80 \%$ of squash water requirements due to the different treatments. The results show that the soil under $R S B_{200}$ retained the highest values of moisture $(15.4-10.6 \%)$ at $(0-40 \mathrm{~cm})$, respectively followed by $C M C_{4}(14.6-9.2 \%), R S B_{100}(14.4-9.6 \%)$ and $C M C_{2}(13.8-9.8 \%)$. Generally, all treatments were higher than control treatment $(13.6-9.8 \%)$. This may be due to the beneficial effect of soil conditioners for moisture retention in soil. These results agree with those of Johnson and Veltkamp (1985).

Squash growth parameters

Figs. (4) and (5) show the relation between growth parameters; plant area "PA" $\left(\mathrm{cm}^{2}\right)$, plant length " $P L^{\prime \prime}(\mathrm{cm})$ and plant leaves number "PLN" (unit) in squash growth stages (ini., dev., and late stages) at different treatments when applying $100 \%$ and $80 \%$ of squash water requirements, respectively. The results reveal that the great values of plant area, plant length and plant leaves number in the growth stages of squash crop (ini., dev., and late stages) were obtained after of $R S B_{200}$ treatment either irrigated $100 \%$ or $80 \%$ from squash water requirements.

Squash marketable yields " ${ }^{\prime \prime}$ ( $k g$ fed $\left.{ }^{-1}\right)$

Fig. (6) illustrate that, the marketable yields of squash were increased due to the application of different conditioners and rates by $6.92,2.25,3.91$ and $0.18 \%$ for $R S B_{200}, R S B_{100}, C M C_{4}$ and $C M C_{2}$, respectively compared to the control treatment (non-conditioned soil) which recorded 7086.27 $k g$ fed $^{-1}$ when irrigated by $100 \%$ of squash water requirements.

Concerning the effect of different treatments on squash marketable yield after irrigation by $80 \%$ from water requirements, Fig. (7) illustrate that, the squash marketable yield were increased due to the application of the some previous conditioners and rates by $16.66,4.14,10.63$ and $3.22 \%$ for $R S B_{200}, R S B_{100}, C M C_{4}$ and $C M C_{2}$, respectively compared to the 
control treatment which recorded $5517.46 \mathrm{~kg} \mathrm{fed}^{-1}$ irrigated by $80 \%$ of squash water requirements.
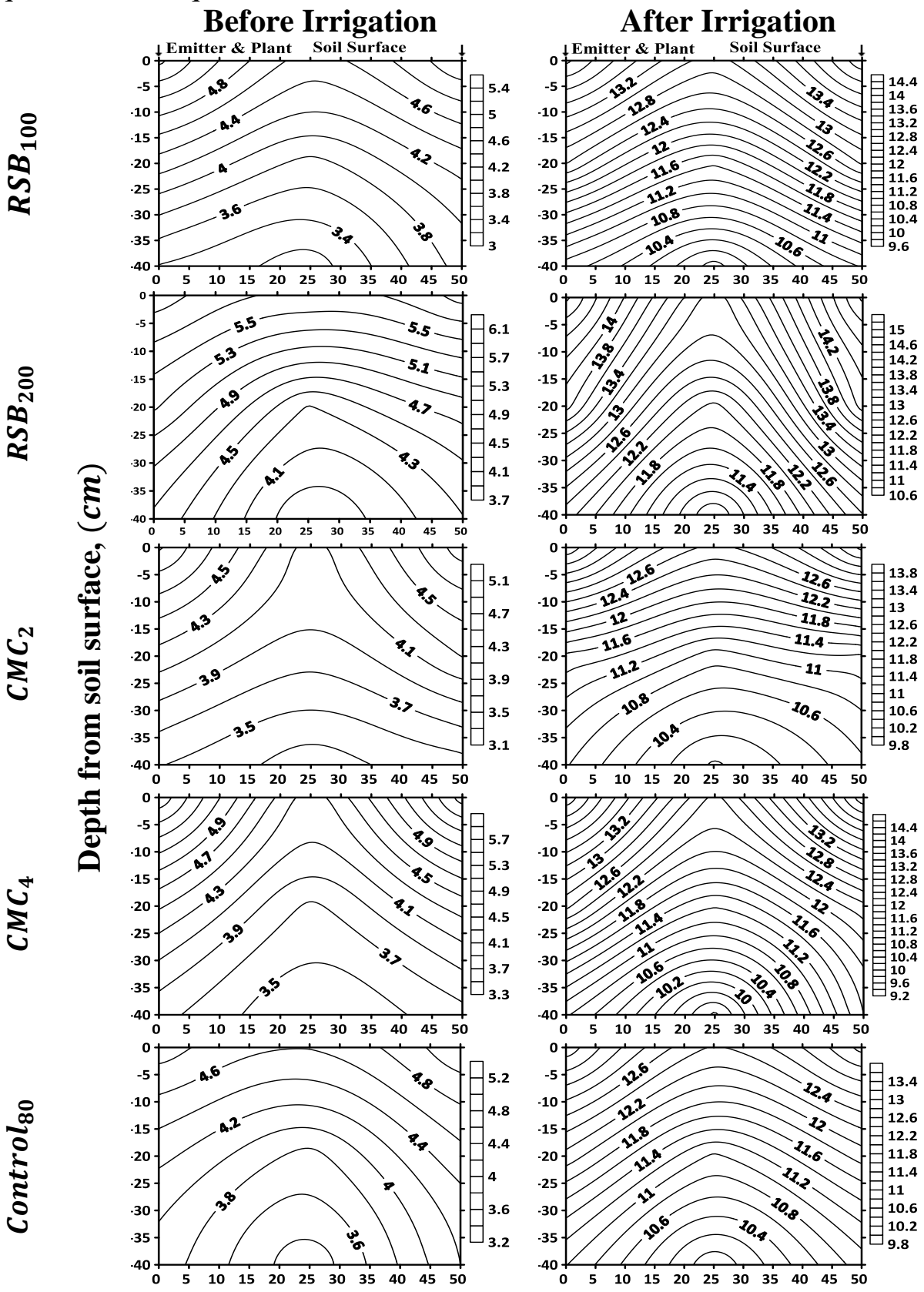

Horizontal distance from emitter or plant, $(\mathrm{cm})$

Fig. (3): The soil moisture distribution pattern in the loamy sand soil between two emitters before irrigation and after two hours of irrigation at applying $80 \%$ of crop evapotranspiration under different treatments. 

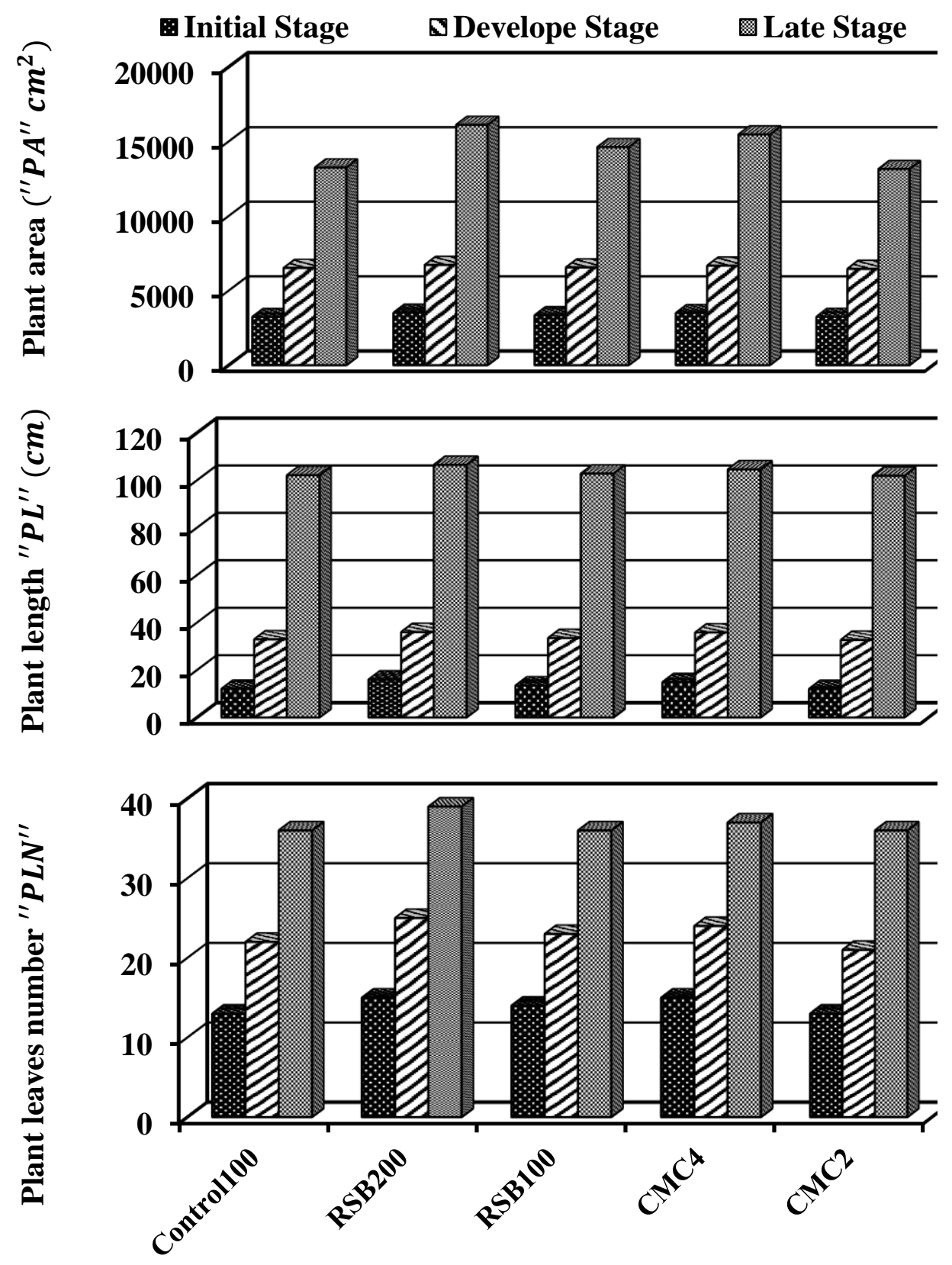

Treatments

Fig. (4): Relation between some growth parameters of squash after the different treatments with applying $100 \%$ of squash water requirements. 

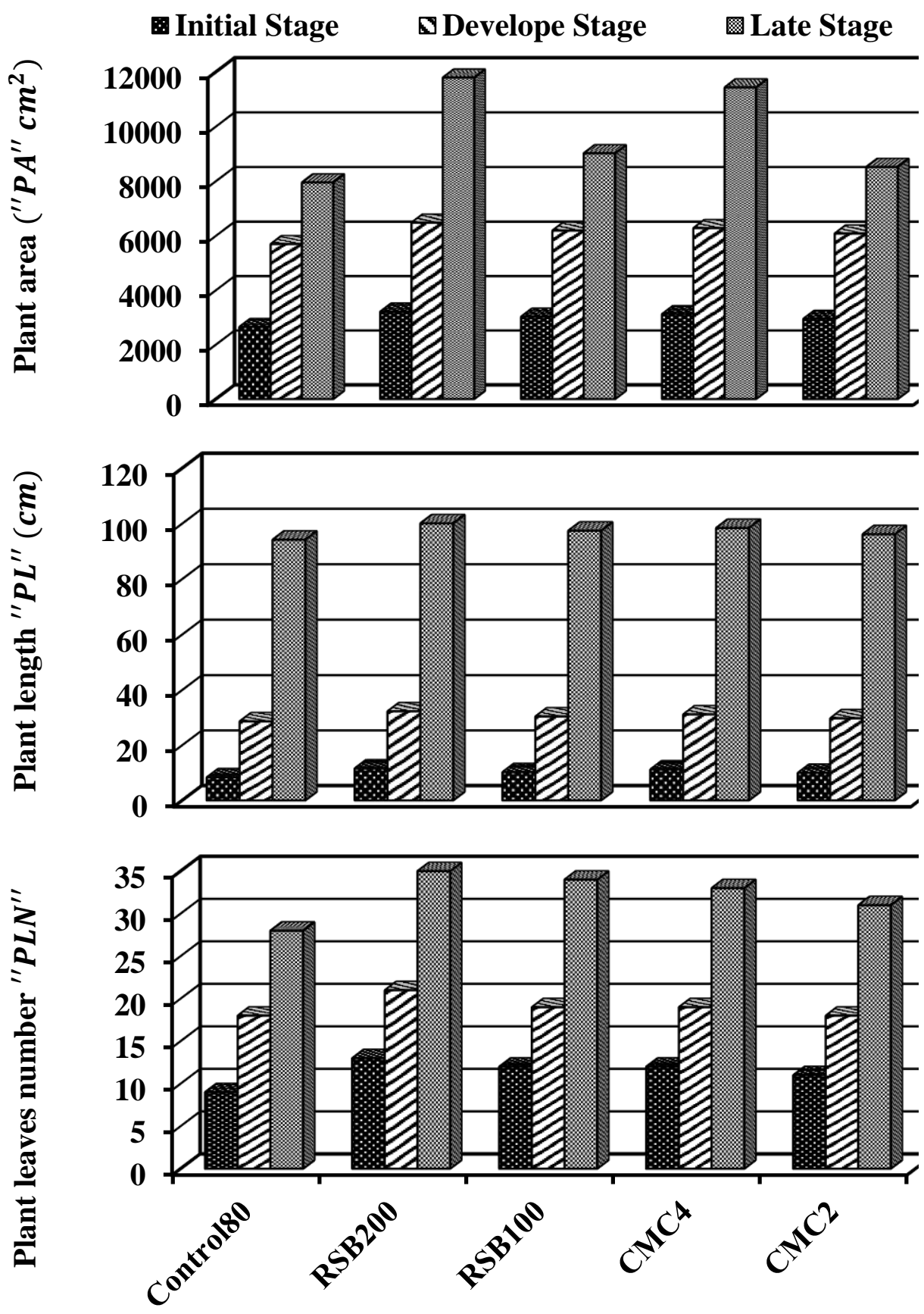

\section{Treatments}

Fig. (5): Relation between some growth parameters of squash after the different treatments with applying $80 \%$ of squash water requirements. 


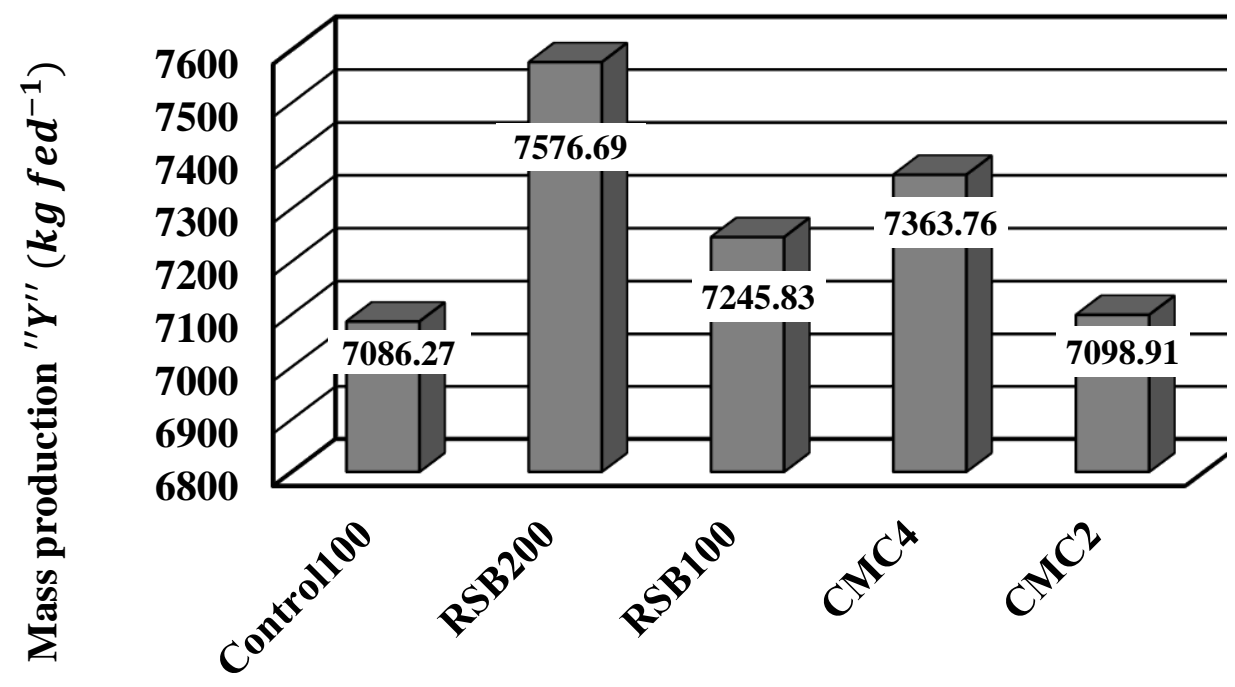

\section{Treatments}

Fig. (6): Relation between mass production $\left(\mathrm{kg} \mathrm{fed}^{-1}\right)$ for the different treatments applying $100 \%$ of squash water requirements.

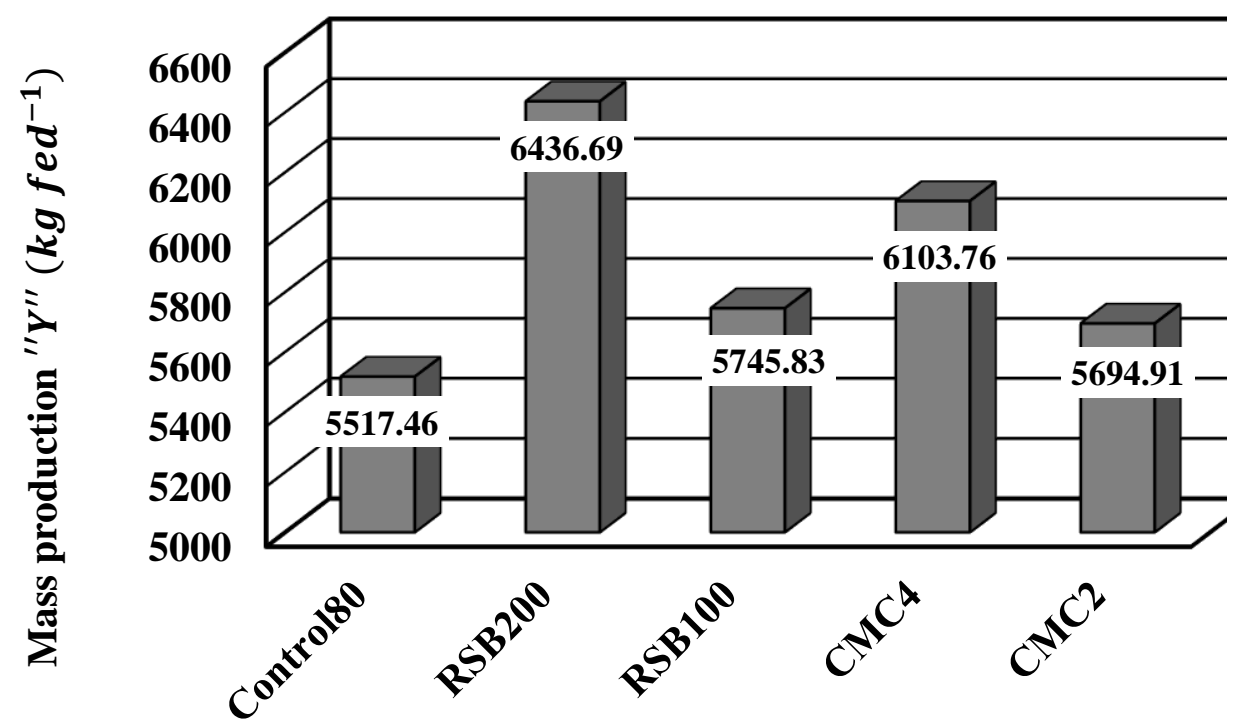

\section{Treatments}

Fig. (7): Relation between mass production $\left(\mathrm{kg} \mathrm{fed}^{-1}\right)$ for the different treatments applying $80 \%$ of squash water requirements.

These results may be due to effect of used conditioners in improvement of soil physical and chemical properties such as soil moisture retention, 
available water, cation exchange capacity and subsequently increasing nutrients availability which is enhance of squash productivity. These results agree well with those of Ali, (2011a).

\section{Irrigation water use efficiency "IWUE" $\left(\mathrm{kg} \mathrm{m}^{-3}\right)$}

Figs. (8) and (9) show the relation between squash production and the total seasonal water used at applying $100 \%$ and $80 \%$ of crop evapotranspiration, respectively.

From Fig. (8) the irrigation water use efficiency was increased due to application of these conditioners by $9.33,8.92,9.07$, and $8.74 \mathrm{~kg} \mathrm{~m}^{-3}$ of seasonal irrigation water for $R S B_{200}, R S B_{100}, C M C_{4}$ and $C M C_{2}$, respectively compared to the control treatment (non-conditioned soil) which recorded $8.72 \mathrm{~kg} \mathrm{~m}^{-3}$ of seasonal irrigation water at applying $100 \%$ of squash water requirements.

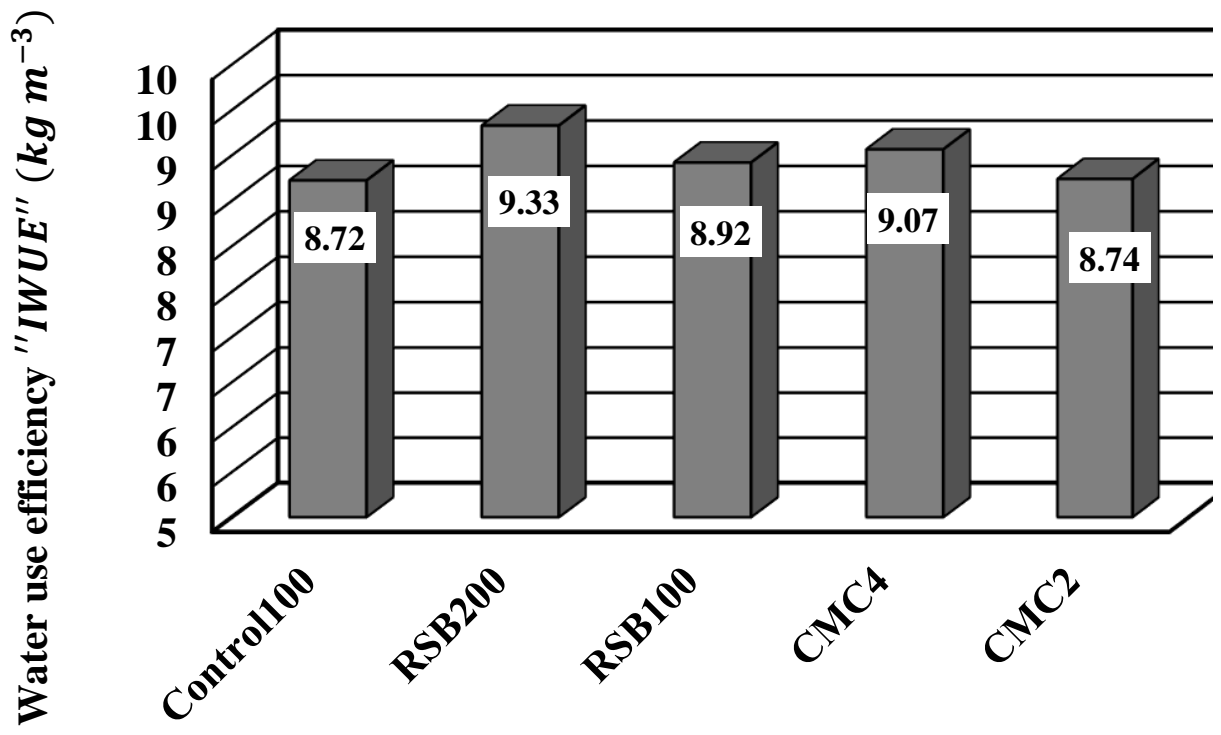

\section{Treatments}

Fig. (8): Relation between irrigation water use efficiency "IWUE" $\left(\mathrm{kg} \mathrm{m}^{-3}\right)$ for the different treatments applying $100 \%$ of squash water requirements.

Also, from Fig. (9) the irrigation water use efficiency was increased due to application of these conditioners by $9.91,8.84,9.39$, and $8.76 \mathrm{~kg} \mathrm{~m}^{-3}$ of seasonal irrigation water for $R S B_{200}, R S B_{100}, C M C_{4}$ and $C M C_{2}$, respectively compared to the control treatment which recorded 8.49 
$\mathrm{kg} \mathrm{m}^{-3}$ of seasonal irrigation water at applying $80 \%$ of squash water requirements.

Data show that treating the sandy soil with tested conditioners led to an increase in water use efficiency by growing plants (yield in $\mathrm{kg} \mathrm{m}^{-3}$ of irrigation water used). These results agree well with those of Ali, (2011a).

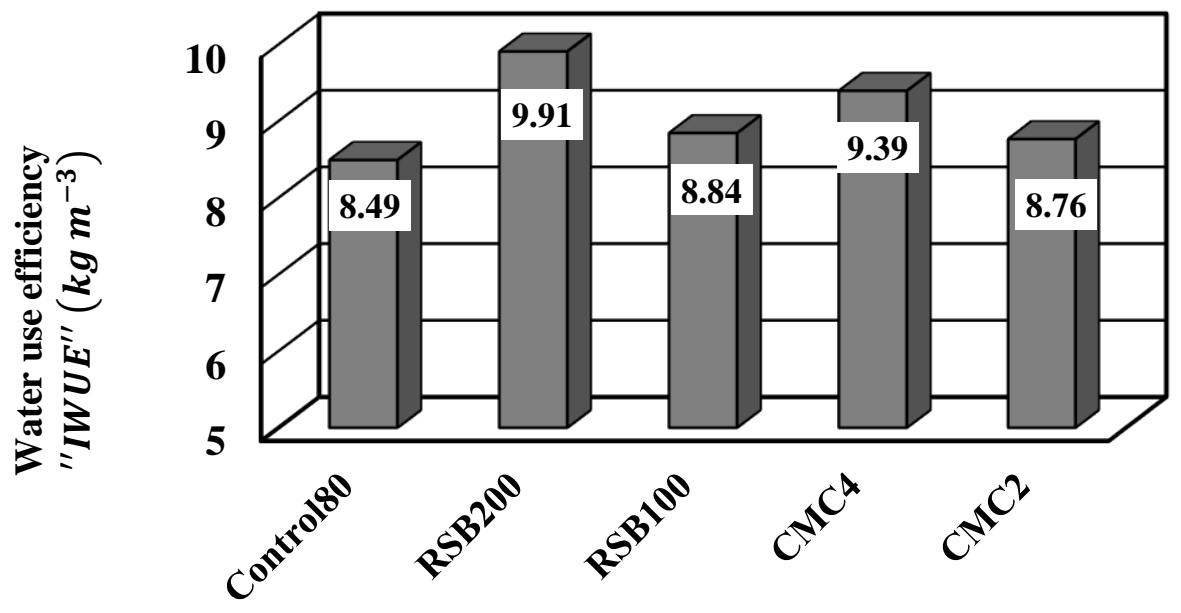

\section{Treatments}

Fig. (9): Relation between irrigation water use efficiency "IWUE" $\left(\mathrm{kg} \mathrm{m}^{-3}\right)$ for the different treatments applying $80 \%$ of squash water requirements.

From the above-mentioned results, it's concluded that the advantage of $R S B$ and $C M C$ conditioners for conserving of irrigation water and increasing the agricultural potentialities of loamy sand soils, enhancing the crop productivity and increasing of water use efficiency.

\section{REFERENCES}

Adel, A.M.; Abou-Youssef, H.; El-Gendy, A.A. and Nada, A.M. (2010). Carboxymethylated cellulose hydrogel sorption behavior and characterization. Nature and Science, 8(8): 244-256.

Ali, L.K. (2011a). Significance of applied cellulose polymer and organic manure for ameliorating hydro-physico-chemical properties of sandy soil and maize yield. Australian J. of Basic and Applied Sci., 5(6): 2335.

Ali, M.H., (2011b). Practices of irrigation \& on-farm water management (Vol. 2). Springer Science \& Business Media. 
Bonelli, P.R.; Della Rocca, P.A.; Cerrella, E.G. and Cukierman, A.L. (2001). Effect of pyrolysis temperature on composition, surface properties and thermal degradation rates of Brazil Nut shells. Bioresource Technology, 76(1):15-22.

Chan, K.Y.; Van Zwieten, L.; Meszaros, I.; Downie, A. and Joseph, S. (2008). Using poultry litter biochars as soil amendments. Soil Res., 46(5): 437-444.

FAO (1998). FAO Irrigation and Drainage Papers. "Crop evapotranspiration - Guidelines for computing crop water requirements". ISSN: 0254-5284. Version: 56.

Johnson, M.S. and Veltkamp, C.J. (1985). Structure and functioning of water-storing agricultural polyacrylamides. J. Sci. of Food and Agric., 36(9): 789-793.

Klute, A. (1986). Methods of soil analysis, part 1 physical and mineralogical methods, Arnold Klute ed. Agronomy. 9, (part 1).

Lal, R. (2008). Soils and sustainable agriculture. A review. Agronomy for Sustainable Development, 28(1): 57-64.

Lehmann, J.; Skjemstad, J.; Sohi, S.; Carter, J.; Barson, M.; Falloon, P.; Coleman, K.; Woodbury, P. and Krull, A.E. (2008). Australian climate-carbon cycle feedback reduced by soil black carbon. Nature Geoscience, 1(12):832-835.

Lu, K.; Yang, X.; Shen, J.; Robinson, B.; Huang, H.; Liu, D.; Bolan, N.; Pei, J. and Wang, H. (2014). Effect of bamboo and rice straw biochars on the bioavailability of $\mathrm{Cd}, \mathrm{Cu}, \mathrm{Pb}$ and $\mathrm{Zn}$ to Sedum plumbizincicola. Agriculture, Ecosystems and Environment, 191: 124132.

Mohamed, E.M.; El-Naggar, A.H.; Usman, A.R. and Al-Wabel, M. (2015). Dynamics of $\mathrm{CO} 2$ emission and biochemical properties of a sandy calcareous soil amended with Conocarpus waste and biochar. Pedosphere, 25(1): 46-56.

Nie, H.; Liu, M.; Zhan, F. and Guo, M., (2004). Factors on the preparation of carboxymethylcellulose hydrogel and its degradation behavior in soil. Carbohydrate Polymers, 58(2): 185-189.

Page, A.L.; Miller, R.H. and Keeny, D.R. (1982). Method of soil analysis. Part 2. Chemical and Microbiological properties 2nd ed. Madison, Wisconsin, USA. 
Papathanasiou, F.; Papadopoulos, I.; Tsakiris, I. and Tamoutsidis, E. (2012). Vermicompost as a soil supplement to improve growth, yield and quality of lettuce (Lactuca saliva L.). Journal of Food, Agriculture and Environment, 10(2): 677-682.

Payero, J.O.; Tarkalson, D.D.; Irmak, S.; Davison, D.R. and Petersen, J.L. (2008). Effect of irrigation amounts applied with subsurface drip irrigation on corn evapotranspiration, yield, water use efficiency and dry matter production in a semiarid climate. Agric. Water Manage., 95(8):895-908.

Sanz, T.; Fernández, M.A.; Salvador, A.; Muñhoz, J. and Fiszman, S.M. (2005). Thermogelation properties of methylcellulose (MC) and their effect on a batter formula. Food Hydrocolloids, 19(1): 141-147.

Singh, B.; Singh, B.P. and Cowie, A.L. (2010). Characterisation and evaluation of biochars for their application as a soil amendment. Soil Research, 48(7):516-525.

Surfer ${ }^{\circledR}$ 15, (2018). Powerful Contouring, Gridding and 3D surface Mapping System, Reference Manual: Golden Software Inc., Golden, $80914^{\text {th }}$ Street, Golden, Colorado 80401-1866, USA.

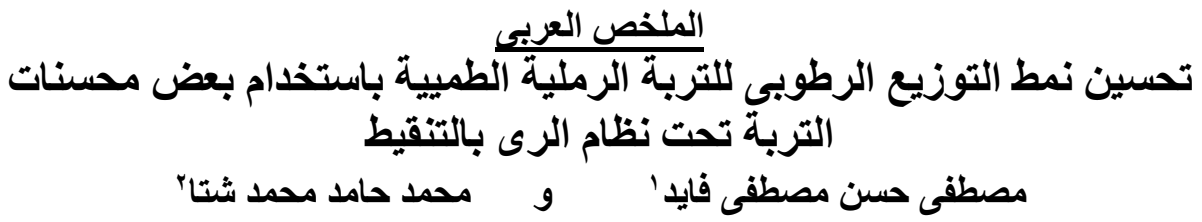

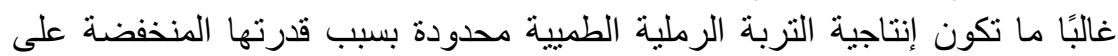

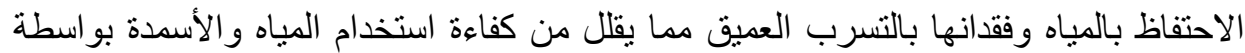

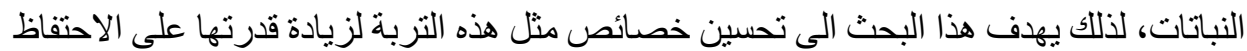

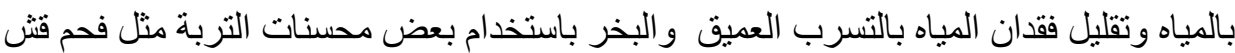

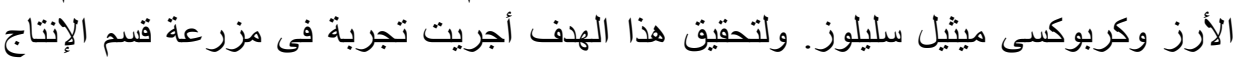

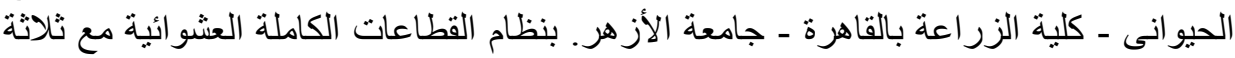

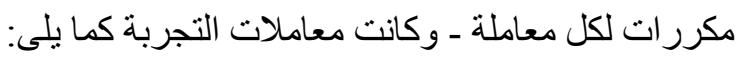

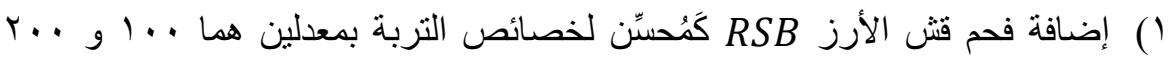

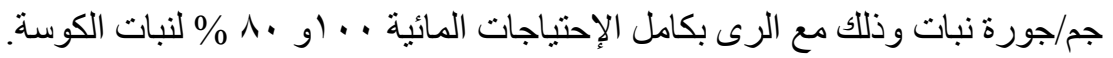

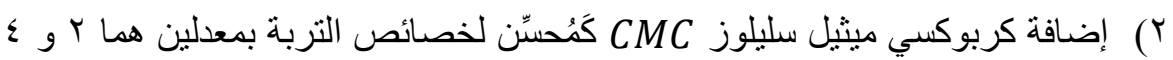

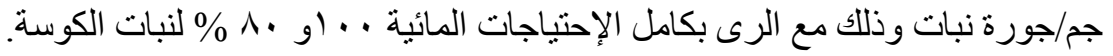

'مدرس بقسم هنسة نظم المياه والرى ـ كلية الهندسة الزراعية بالقاهرة - جامعة الأزهر. 'مدرس بقسم الأراضى والمياه ـ كلية الزراعة بالقاهرة - جامعة الأزهر. 


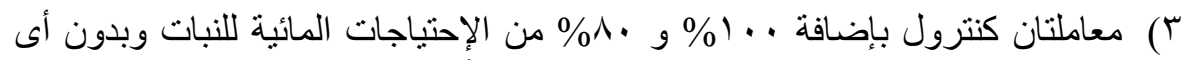
إضافات للتربة من محسنات التربة المستخدمة سابقاً.

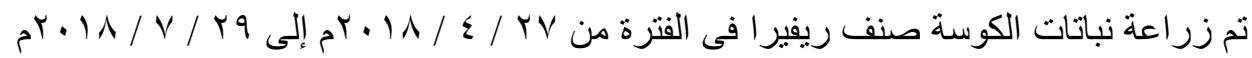
تحت نظام الرى بالتنقيط للمعاملات السابقة ـ وتم أخذ القياسات التالية التية:

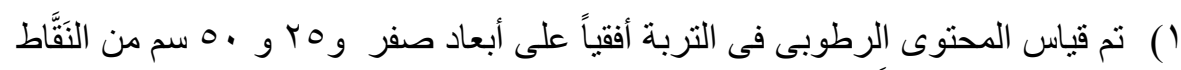

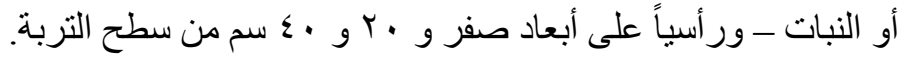

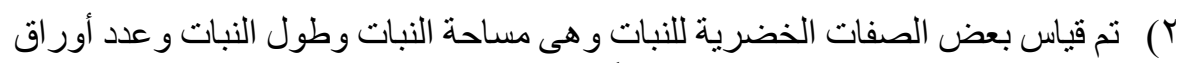

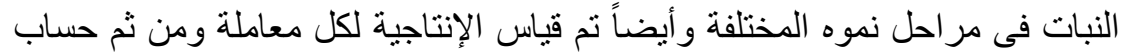
كفاءة استخدام المياه لكل المعاملات

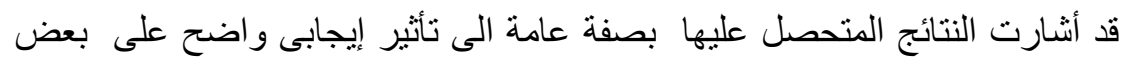

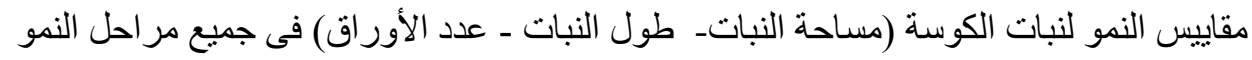

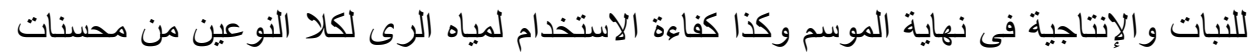

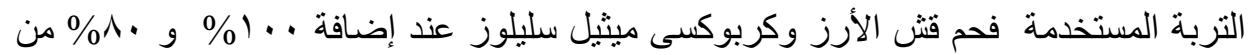

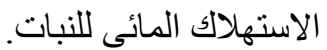

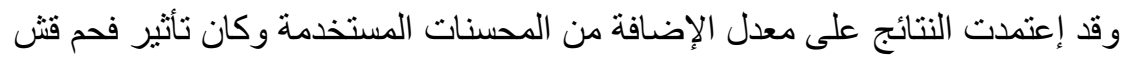
الأرز على المحصول لنبات الكوسة أعلى من كربوكسى ميثيل سليلوز - وكاتت أهم النئ النتائج

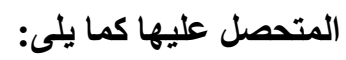

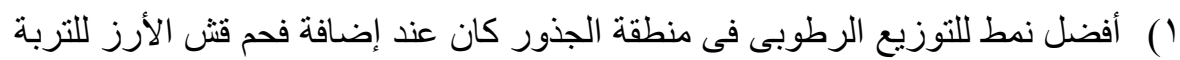

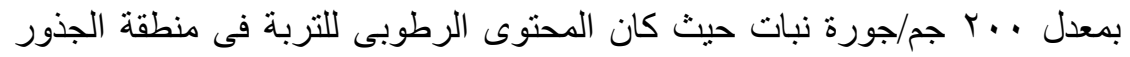

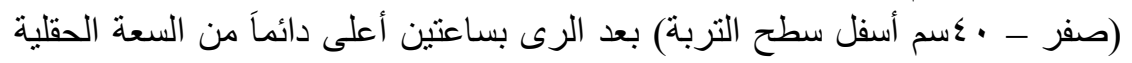

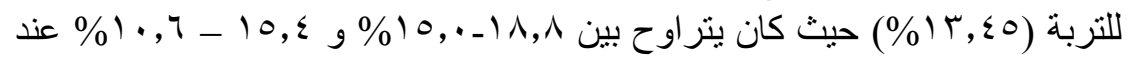

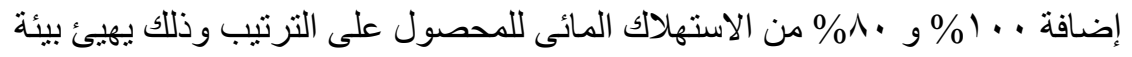

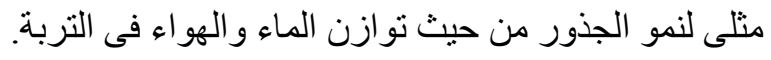

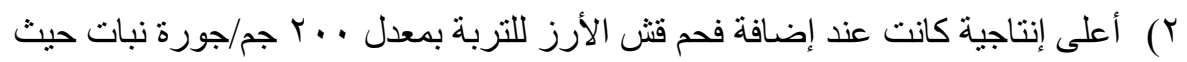

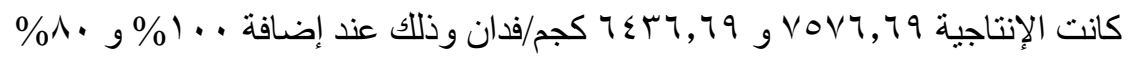
من الاستهلاك المائى للنبات على الترتيب.

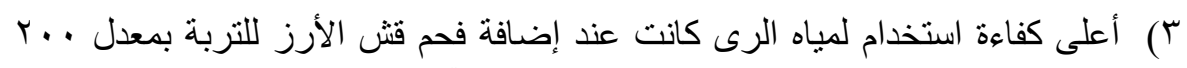

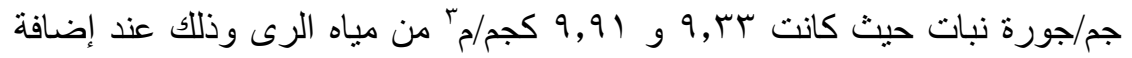

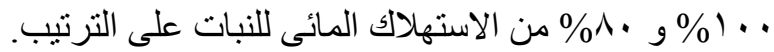

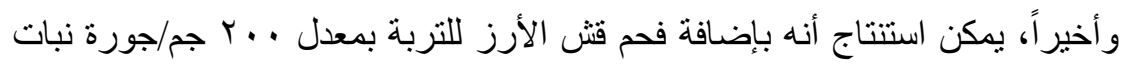

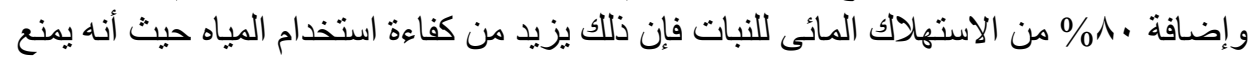

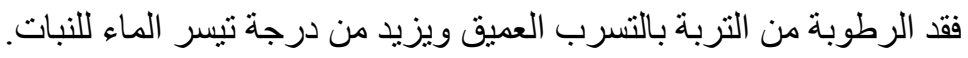

